\title{
Effect of soluble silica fertiliser on total sugar, protein, starch content along with amylase and cellulase activity in banana
}

\author{
Tasneem Rangwala ${ }^{1 *}$, Angurbala Bafna ${ }^{1}$, Nagesh Vyas $^{2} \&$ Rohan Gupta ${ }^{2}$ \\ ${ }^{1}$ Department of Biochemistry, Govt. Holkar Science College, Indore 452 017, M.P., India \\ ${ }^{2}$ Noble Alchem Pvt. Ltd., Sanwer Road, Indore (Madhya Pradesh), India \\ *Email: tasneemdharwala@yahoo.com
}

\section{ARTICLE HISTORY}

Received: 18 January 2021

Accepted: 13 February 2021

Published: 01 April 2021

\section{KEYWORDS}

Agribooster; Burhanpur district (Madhya Pradesh); Grand naine variety; ripening.

\begin{abstract}
Fertilisers have become an important factor used by farmers to increase yield and improve product quality. Earth's crust carries a large amount of elemental silicon. However, silicon is not considered an essential element for plant growth therefore is not included in fertilisers. Silicon has shown to enhance the growth and productivity of various crops. The present study aimed to explore the potential of soluble silica in improving the biochemical parameters of banana (Grand naine variety). The field experiment was conducted at Ropni Vasaad village, Burhanpur District of Madhya Pradesh from August 2017 to September 2018. Silica was supplied as potassium silicate in the liquid form under the trade name Agribooster ${ }^{\mathrm{TM}}$. Doses were administered at the interval of one month starting from planting the tissue culture explants till harvesting the final crop. Eight treatments were designed which included three different concentration of soluble silica applied alone and with combination with compound fertilisers. Control was without any treatment. A significant increase in fresh and dry weight was observed with all the treatments. All the combinations of soluble silica resulted in significant increase in starch and total sugar content. The protein content showed significant increase with treatments consisting of soluble silica and compound fertiliser. Cellulase and amylase activity declined on treatment with soluble silica. The present study reveals that if soluble silica is either applied alone or with compound fertiliser, it can enhance the biochemical parameters and can indirectly delay ripening of banana by altering activity of cellulase and amylase.
\end{abstract}

\section{Introduction}

Silicon, a metalloid is present in a huge amount in the crust of the earth. Silicon bonded with oxygen atoms is known as silicon dioxide or silica $\left(\mathrm{SiO}_{2}\right)$. Silicon exists in a various complicated form such as oxides or aluminosilicates in earth's crust. Weathering of silicates from soil either through chemical or physical agents results in the release of silicon from the complex form, which then combines with clay or is taken up by the vegetation (1). Although silicon is present in the large amount, its role in the survival and growth of plants in the absence of any stress is not fully understood. In the present agriculture system, silicon is not counted essential for the growth of plants. Most of the silicon present in the soil is unavailable for uptake by the plants (2). Plants can absorb silica as silicic acid which gets deposited in plants in the form of amorphous silica (3).
Silicon is believed to show many positive effects in plants though not considered essential element (4). Silicon is reported to improve the tolerance of plants against drought stress by maintaining water balance and increasing photosynthesis (5). The increased yield was reported with the application of silicon in wheat exposed to water deficit stress (6). Treatment of wheat exposed to salt stress with calcium silicate showed an increase in growth (7). Incorporating silicon in hydroponic solution even in low concentration increased potassium uptake (8). Silicon is accumulated and distributed by different plant species in different ways depending on its uptake and transport. Species under the family Poaceae like rice (9), wheat (10) have a mechanism for active transport of silica. Accumulation of polysilicic acid in plants is behind the defensive role of silicon (11).

(c) Rangwala et al. (2021). This is an open-access article distributed under the terms of the Creative Commons Attribution License, which permits unrestricted use, distribution and reproduction in any medium, provided the original author and source are credited (https://creativecommons.org/licenses/by/4.0/).

To cite this article: Rangwala T, Bafna A, Vyas N, Gupta R. Effect of soluble silica fertiliser on total sugar, protein, starch content along with amylase and cellulase activity in banana. Plant Science Today. 2021;8(2):283-288. https://doi.org/10.14719/pst.2021.8.2.1032

Plant Science Today, published by Horizon e-Publishing Group, is covered by Scopus, Web of Science, BIOSIS Previews, Clarivate Analytics, etc.

Full list at http://www.plantsciencetoday.online 
Banana plant is perennial, large and has pseudo stem which consists of leaves packed tightly in the sheath (12). In developing countries, production of banana play major role in supporting economy and providing employment for the local populations (13). Banana is a good source of carbohydrate and minerals such as potassium, calcium, magnesium, sodium and phosphorus (14). Banana is fruit obtained from herbaceous plant of Musa. Banana plant is one of the accumulators of silicon (15). An increase in resistance of plants can help in better growth and productivity. The present study was conducted to evaluate potential of the silicon fertiliser in the form of soluble silica in enhancing the biochemical parameters and delaying ripening of banana by slowing activity of amylase and cellulose enzyme.

\section{Materials and Methods}

The experiment was conducted in the field situated at coordinates 21.359222, 76.275389, Ropni Vasaad Village, Burhanpur District, Madhya Pradesh. Tissue culture explants of banana variety Grand naine obtained from Jain Tissue Culture, Maharashtra were planted in rows $1.5 \mathrm{~m}$ apart and two plants separated by the distance of $1.7 \mathrm{~m}$. The analysis of soil (Table 1) was done by collecting soil samples from different part of field before sowing the banana explants. hrs. After cooling, the extract was neutralised with sodium carbonate till effervescence halts. Supernatant collected in $100 \mathrm{ml}$ volumetric flask after centrifugation (REMI R-8C) for 15 minutes at 5000 rpm and diluted upto $100 \mathrm{ml}$ with distilled water. 0.5 $\mathrm{ml}$ of sample aliquot was used and diluted to $1 \mathrm{ml}$ with distilled water. $4 \mathrm{ml}$ anthrone reagent was added and boiled for $10 \mathrm{~min}$ and the optical density of the resulting green colour solution was taken at $630 \mathrm{~nm}$ using digital spectrophotometer (CHEMILINE, CL- 320). Total carbohydrate content was expressed as \% $\mathrm{mg}$.

Starch content: To remove sugars, a 0.1 gm sample was homogenised with $5 \mathrm{ml}$ of hot $80 \%$ ethanol. It was centrifuged at $5000 \mathrm{rpm}$ for $15 \mathrm{~min}$ and the residue was repeatedly washed with hot $80 \%$ ethanol till the washings become colourless with anthrone. The residue was dried over water bath (BIOTECHNICS INDIA, BTI 57) $5 \mathrm{ml}$ of water and 6.5 $\mathrm{ml}$ of $52 \%$ perchloric acid was added to the residue. Content was centrifuged in refrigerated centrifuge (Remi, $16 \mathrm{R}$ ) at $15000 \mathrm{rpm}$ for $20 \mathrm{~min}$ at $0{ }^{\circ} \mathrm{C}$. The residue was again extracted using perchloric acid and supernatant obtained was pooled with the previous supernatant and diluted upto $100 \mathrm{ml} .0 .2 \mathrm{ml}$ aliquot of the sample was diluted up to $1 \mathrm{ml}$ and mixed with $4 \mathrm{ml}$ anthrone reagent. The tube was boiled in water bath for $8 \mathrm{~min}$ and absorbance was recorded at $630 \mathrm{~nm}$ using anthrone as blank (17).

Table 1. Analysis of soil samples for macronutrients before sowing Banana tissue culture explants

\begin{tabular}{|c|c|c|c|c|c|c|}
\hline Treatments & pH(1:2) & $\begin{array}{c}\text { Electrical } \\
\text { Conductivity(1:2) } \\
\mathrm{dSm}^{-1}\end{array}$ & $\begin{array}{c}\text { Organic } \\
\text { Carbon } \\
(\%)\end{array}$ & $\begin{array}{c}\text { Available } \\
\text { Nitrogen } \\
\text { (kg/ha) }\end{array}$ & $\begin{array}{c}\text { Available } \\
\text { Phosphorus } \\
\text { (kg/ha) }\end{array}$ & $\begin{array}{c}\text { Available } \\
\text { Potash } \\
\text { (kg/ha) }\end{array}$ \\
\hline Before Treatment & 7.24 & 1.52 & 0.45 & 190 & 11.2 & 480 \\
\hline Optimum value for Comparison & $6.5-7.50$ & $<0.80$ & 0.50 & $250-400$ & $>10$ & 400 \\
\hline
\end{tabular}

Fertilisers were not applied in the field used for the study for about three months to get unbiased result. Compound fertiliser used in the treatments consists of urea (6 Kg/1000 plants), potash (6 Kg/ 1000 plants), magnesium (2 Kg/ 1000 plants) and NPK 12:61:0 (2.5 $\mathrm{Kg} / 1000$ plants). 15 plants were present in a single row. Mode of irrigation was drenching and approximately 10 litre water was supplied to each plant every day. Randomised block design was used for following eight treatments: control (only irrigated with water), T1 (compound fertiliser only), T2 (0.75 $\mathrm{ml} /$ lit silica), T3 (1 ml/ lit silica), T4 (1.25 ml/ lit silica), T5 (0.75 ml/lit silica + compound fertiliser), T6 (1 $\mathrm{ml} /$ lit silica + compound fertiliser), T7 $(1.25 \mathrm{ml} / \mathrm{lit}$ silica + compound fertiliser). Silica was given in liquid, soluble form as potassium silicate under the trade name Agribooster ${ }^{\mathrm{TM}}$.

After harvesting of fruit, banana pulp was analysed for the following parameters:

Fresh weight-: It was determined for single banana using an electronic balance (S.D. Fine Che. Limited, SD300) and was expressed in gm.

Dry weight-: It was determined after keeping fresh banana in an oven (Unix 96) at $80^{\circ} \mathrm{C}$ for $18-20$ hrs and expressed in gm.

Total sugar content-: Total sugar content was estimated in banana using anthrone reagent (16). 0.1 gm sample was boiled with $5 \mathrm{ml}$ of $2.5 \mathrm{~N} \mathrm{HCl}$ for 3
Protein content-: The estimation of protein was determined as per standard procedure (18). $200 \mathrm{mg}$ of sample was homogenised in $5 \mathrm{ml}$ distilled water. The tube was centrifuged at $3000 \mathrm{rpm}$ for $15 \mathrm{~min}$ and in supernatant collected, $5 \mathrm{ml}$ of trichloroacetic acid was added and allowed to stand for $30 \mathrm{~min}$ for precipitation of protein. Precipitate collected by centrifugation for $10 \mathrm{~min}$ was dissolved in $5 \mathrm{ml}$ of 0.1 $\mathrm{N} \mathrm{NaOH}$. $0.2 \mathrm{ml}$ of this was diluted up to $1 \mathrm{ml}$ with distilled water and $5 \mathrm{ml}$ of Reagent $\mathrm{C}$ (was added followed by incubation for $15 \mathrm{~min}$. To this, $0.5 \mathrm{ml}$ of folin phenol reagent was added and after $30 \mathrm{~min}$ absorbance of the solution was noted at $660 \mathrm{~nm}$. Protein content was estimated using a standard curve prepared with 40-200 $\mu \mathrm{g}$ of BSA.

Amylase activity-: 2 gm of sample was homogenised using $5 \mathrm{ml}$ of $0.1 \mathrm{M}$ phosphate buffer (pH 7). After centrifugation at $4^{\circ} \mathrm{C}$ for $20 \mathrm{~min}$ at $15000 \mathrm{rpm}, 1 \mathrm{ml}$ of supernatant (enzyme source) was mixed with $1 \mathrm{ml} 1$ $\%$ starch solution and incubated for $15 \mathrm{~min}$. The reaction was stopped by the addition of $2 \mathrm{ml}$ DNS (dinitrosalicylic acid) reagent. Another tube containing $1 \mathrm{ml}$ of starch in which $1 \mathrm{ml}$ of supernatant was added before the addition of $2 \mathrm{ml}$ DNS served as control. $1 \mathrm{ml}$ phosphate buffer added to $1 \mathrm{ml}$ starch and $2 \mathrm{ml}$ DNS reagent was used as blank. $1 \mathrm{ml}$ starch, $0.9 \mathrm{ml}$ buffer, $0.1 \mathrm{ml}$ maltose (1 $\mathrm{mg} / \mathrm{ml}$ ) and $2 \mathrm{ml}$ DNS reagent containing tube served as standard. All the tubes were kept in boiling water 
bath for $5 \mathrm{~min}$. After this $1 \mathrm{ml}$ Rochelle salt solution was added in all the tubes. Tubes were cooled and diluted up to $10 \mathrm{ml}$ with distilled water. The absorbance of the above solution was measured at $560 \mathrm{~nm}$. The activity of enzyme was expressed as $\mu \mathrm{g}$ maltose liberated/mg protein/min (19).

Cellulase activity: $2 \mathrm{gm}$ of the sample was extracted with $5 \mathrm{ml} 0.1 \mathrm{ml}$ citrate buffer ( $\mathrm{pH} 5)$ and centrifuged at $15000 \mathrm{rpm}$ for 20 minutes at $4{ }^{\circ} \mathrm{C}$. The supernatant was used as an enzyme source. The reaction mixture for the test was prepared by adding $0.45 \mathrm{ml}$ of $1 \%$ carboxy methyl cellulose, $0.05 \mathrm{ml}$ of enzyme source and incubated at $37^{\circ} \mathrm{C}$ for $15 \mathrm{~min}$. The reaction was terminated using $2 \mathrm{ml}$ DNS reagent. Blank was prepared similarly as test only instead of $0.05 \mathrm{ml}$ enzyme source, $0.05 \mathrm{ml}$ citrate buffer was added. In the control $0.05 \mathrm{ml}$ supernatant was added after adding $2 \mathrm{ml}$ DNS reagent. Standard was prepared with $0.45 \mathrm{ml} \mathrm{CMC}, 0.05 \mathrm{ml}$ of glucose $(1 \mathrm{mg} / \mathrm{ml})$ and 2 $\mathrm{ml}$ DNS reagent. All the tubes were kept in a boiling water bath for $5 \mathrm{~min}$. After this, $1 \mathrm{ml}$ Rochelle salt solution was added to all the tubes. Tubes were cooled and diluted up to $10 \mathrm{ml}$ with distilled water. The absorbance of the above solution was taken at $560 \mathrm{~nm}$. The activity of enzyme was expressed as $\mu \mathrm{g}$ glucose liberated/mg protein/min (19).

Statistical analysis: Observations are represented as the mean of three replicates of experiment. Data were expressed as mean \pm SD. p-value was calculated to test significance in difference. One way ANOVA was used to determine the difference between the various concentration of soluble silica used. The correlation coefficient was calculated by Pearson's method. All statistical analysis was done using MS Excel 2017.

\section{Results and Discussion}

\section{Effect of soluble silica fertiliser on growth attributes of banana}

Fresh weight of banana showed significant increase till T5 treatment as compared to control and T1 treatment (Table 2). Fig. 1 shows that the highest fresh weight $(44.86 \%)$ was found with T2 treatment ( $0.75 \mathrm{ml} / \mathrm{L}$ soluble silica only). Silicon induced water retention and enhanced concentration of macromolecules may have increased the fresh weight of banana. Dry weight was found to increase significantly in all the treatments except $\mathrm{T} 2$ and $\mathrm{T} 7$ relative to control. No significant change was observed in dry weight when collated with T1 treatment (only fertiliser). Dry weight showed maximum peak (95.36\%) with T5 treatment.
Epidermal deposition of silicon leads to decrease in the rate of transpiration resulting in water retention (20). Improved growth of non-Lead stress cotton under the influence of silicon was reported in an earlier study (21). Supplementation of $0.5 \mathrm{~kg} / \mathrm{L}$ of $\mathrm{K}_{2} \mathrm{SiO}_{3} \cdot \mathrm{nH}_{2} \mathrm{O}$ to medicinal honeysuckle plant with and without salt stress showed a maximum increase in fresh and dry weight (22). Beneficial role of silicon in enhancing fresh and dry weight in salinity stressed cherry tomatoes was also reported (23).

\section{Effect of soluble silica fertiliser on biochemical attributes of banana}

A significant increase in total sugar content was observed with all the treatment except T4 and T6 (Fig. 3). Total sugar content was increased maximally with T3 treatment. A study conducted on banana cv. Neypoovan revealed improvement in the fruit quality like reducing and non-reducing sugar content on application of silicon at the rate $4 \mathrm{ml}$ and $2 \mathrm{ml} / \mathrm{L}$ through foliar spray (24). Protein content in banana resulted in a significant increase from $\mathrm{T} 5$ to $\mathrm{T} 7$ treatment (Fig. 2). Similar results were reported earlier in an experiment involving supplementation of silicon in cucumber and wheat grew under saline and water stress respectively $(25,26)$. Silicon was thought to be actively involved in the synthesis of specific proteins using amino acid (27) and the process of transcription along with translation (28). Even in the absence of lead, silicon resulted in increase in protein content of cotton (21). Increased protein content was reported in soybean by the application of silicon (29).

A significant increase was observed in starch content with all the combinations of silica relative to both control and T1 treatment (Fig. 4). As shown in Table 3, amylase and cellulase activity were decreased significantly under the influence of silica treatment when compared with control as well as T1 treatment. Amylase and cellulase activity is indicator of the ripening process of banana (30). Degradation of the cell wall and softening of tissue in banana during ripening is controlled by the activity of cellulase enzyme. An increase in fruit firmness of tomato under influence of silicon was earlier reported (31). The decrease in activity of amylase and cellulase in the presence of silica (Fig. 5) indicates delayed ripening which increases the shelf life of banana. Reduced expression of genes coding cellulase and amylase enzymes may be the reason behind the decreased activity of these enzymes. An increase in starch content during ripening was attributed to decreased activity of the amylase enzyme (32).

Table 2. Fresh weight, dry weight, total carbohydrate and protein content in the pulp of banana obtained after different treatments from planting till harvesting

\begin{tabular}{|c|c|c|c|c|c|}
\hline Sl. No. & Treatments & Fresh weight (gm) & Dry weight (gm) & Total sugar (\%mg) & Protein (mg/gm) \\
\hline 1. & Control & $66.09 \pm 5.71$ & $9.49 \pm 0.89$ & $14.83 \pm 1.52$ & $1.93 \pm 0.07$ \\
\hline 2. & T1 & $80.62 \pm 2.08 \mathrm{a} *(21)$ & $13.43 \pm 2.05 \mathrm{a}^{*}(41.5)$ & $19.83 \pm 1.52 \mathrm{a}^{*}(33.71)$ & $3.06 \pm 0.98 \mathrm{a}^{\mathrm{NS}}(58.5)$ \\
\hline 3. & $\mathrm{~T} 2$ & $95.74 \pm 8.07 \mathrm{a}^{* *}, \mathrm{~b} *(44.86)$ & $13.41 \pm 2.54 \mathrm{a}^{\mathrm{NS}}, \mathrm{b}^{\mathrm{NS}}(41.3)$ & $19.83 \pm 0.57 a^{*}, b^{\mathrm{NS}}(33.71)$ & $2.55 \pm 0.47 \mathrm{a}^{\mathrm{NS}}, \mathrm{b}^{\mathrm{NS}}(32.1)$ \\
\hline 4. & T3 & $85.56 \pm 1.75 a^{* *}, b^{*}(28.6)$ & $14.81 \pm 0.63 \mathrm{a}^{* * *}, \mathrm{~b}^{\mathrm{NS}}(56)$ & $22.5 \pm 1.32 \mathrm{a}^{* *}, \mathrm{~b}^{\mathrm{NS}}(51.7)$ & $2.08 \pm 0.10 a^{\mathrm{NS}}, \mathrm{b}^{\mathrm{NS}}(7.7)$ \\
\hline 5. & T4 & $85.49 \pm 3.42 \mathrm{a}^{* *}, \mathrm{~b}^{\mathrm{NS}}(29.3)$ & $15.25 \pm 0.45 \mathrm{a}^{* * *}, \mathrm{~b}^{\mathrm{NS}}(60.6)$ & $14.83 \pm 1.75 \mathrm{a}^{\mathrm{NS}}, \mathrm{b}^{*}(0)$ & $1.93 \pm 0.07 \mathrm{a}^{\mathrm{NS}}, \mathrm{b}^{\mathrm{NS}}(0)$ \\
\hline 6. & T5 & $91.54 \pm 4.33 \mathrm{a}^{* *}, \mathrm{~b}^{*}(38.5)$ & $18.54 \pm 1.28 \mathrm{a}^{* * *}, \mathrm{~b}^{\mathrm{NS}}(95.36)$ & $20.66 \pm 0.57 a^{* *}, b^{N s}(39.3)$ & $4.78 \pm 0.67 a^{* * *}, b^{\mathrm{NS}}(147)$ \\
\hline 7. & T6 & $74.14 \pm 2.71 \mathrm{a}^{\mathrm{NS}}, \mathrm{b}^{*}(12.1)$ & $13.26 \pm 0.89 a^{* *}, b^{N S}(39.7)$ & $17.16 \pm 0.48 \mathrm{a}^{\mathrm{NS}}, \mathrm{b}^{*}(15.71)$ & $4.51 \pm 0.38 \mathrm{a}^{* * *}, \mathrm{~b}^{\mathrm{NS}}(133)$ \\
\hline 8. & T7 & $61.86 \pm 6.35 \mathrm{a}^{\mathrm{NS}}, \mathrm{b}^{* *}(-6.40)$ & $10.71 \pm 1.22 \mathrm{a}^{\mathrm{NS}}, \mathrm{b}^{\mathrm{NS}}(12.8)$ & $21.16 \pm 1.89 a^{* *}, b^{N S}(42.6)$ & $4.5 \pm 0.26 \mathrm{a}^{* * *}, \mathrm{~b}^{\mathrm{NS}}(133)$ \\
\hline
\end{tabular}

a indicates $\mathrm{p}$ value compared to control and $\mathrm{b}$ indicates $\mathrm{p}$ value compared to T1. ${ }^{*} \mathrm{p}$ value $<0.05$, ${ }^{* *} \mathrm{p}$ value $<0.01,{ }^{* * *} \mathrm{p}$ value $<0.001$.

Parenthesis indicates percent increase or decrease compared to control. 


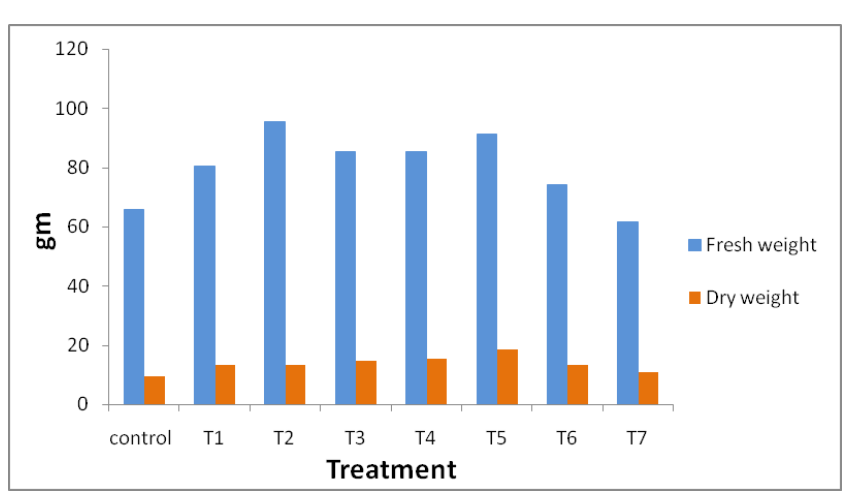

Fig. 1. Fresh and dry weight of banana collected after different treatments from planting till harvesting.

A significant difference in $\mathrm{F}$ value as calculated by ANOVA single factor was observed with fresh weight, dry weight, total sugar content and amylase activity between T5, T6, T7 treatment (Table 4). F value between $\mathrm{T} 2, \mathrm{~T} 3$ and $\mathrm{T} 4$ treatment showed significant difference in total sugar content, starch content and amylase activity. This indicates that different concentration of soluble silica alone and with routine fertiliser does not show similar effect on different biochemical attributes and enzymatic parameters. However, all the treatments involving soluble silica showed positive effect in improving biochemical content in banana.

Correlation expressed in terms of Pearson coefficient showed a significant positive correlation between fresh and dry weight, cellulase and amylase activity. Maturation and ripening of banana are indicated with the interaction of various enzymes viz. amylase, cellulase and starch content (30). As shown in Table 5, starch content has a significant negative correlation with amylase and cellulase enzyme activity. It was observed that starch content in banana is related to the activity of amylase enzyme (33). An inverse relationship between starch content and amylase activity was reported in a study conducted on banana (30). Reports are also on an inverse correlation between starch and amylase activity in avocado fruit pulp (34).

\section{Conclusion}

Soluble silica when used from planting to harvesting of banana crop improved the quality of harvested banana and also delayed its ripening. When soluble silica was used with routine fertiliser synergistic effect was produced and significant positive change was observed in biochemical parameters of banana. This indicates that soluble silica when applied along with compound fertiliser can result in good quality product.

\section{Acknowledgements}

We express our sincere thanks to $\mathrm{Dr}$ Suresh $\mathrm{T}$. Silawat, Principal, Govt. Holkar Science College Indore, Madhya Pradesh for providing necessary laboratory facilities and encouragement.

Table 3. Starch content, amylase and cellulase activity in the pulp of banana obtained after different treatments from planting till harvesting

\begin{tabular}{|c|c|c|c|c|}
\hline Sl.No. & Treatments & Starch (\% mg) & $\begin{array}{c}\text { Amylase activity ( } \mu \text { g maltose/mg } \\
\text { protein/min) }\end{array}$ & $\begin{array}{c}\text { Cellulase activity ( } \mu \text { g glucose/mg } \\
\text { protein/min) }\end{array}$ \\
\hline 1. & Control & $6.66 \pm 2.25$ & $0.916 \pm 0.01$ & $2.91 \pm 0.15$ \\
\hline 2. & $\mathrm{~T} 1$ & $10.16 \pm 0.28 a^{\mathrm{NS}}(52.5)$ & $0.802 \pm 0.08 a^{\mathrm{NS}}(-12.44)$ & $2.87 \pm 0.46 \mathrm{a}^{\mathrm{NS}}(1.37)$ \\
\hline 3. & $\mathrm{~T} 2$ & $14.66 \pm 0.76 \mathrm{a}^{* * *}, \mathrm{~b}^{* * *}(120)$ & $0.48 \pm 0.07 \mathrm{a}^{* * *}, \mathrm{~b}^{* * *}(-47.59)$ & $1.32 \pm 0.25 \mathrm{a}^{* * *}, \mathrm{~b}^{* * *}(-54.3)$ \\
\hline 4. & T3 & $13.16 \pm 1.04 \mathrm{a}^{*}, \mathrm{~b}^{* * *}(97)$ & $0.62 \pm 0.04 \mathrm{a}^{* * *}, \mathrm{~b}^{*}(-32.31)$ & $0.86 \pm 0.14 \mathrm{a}^{* * *}, \mathrm{~b}^{* * *}(-70.4)$ \\
\hline 5. & $\mathrm{~T} 4$ & $11.83 \pm 0.28 \mathrm{a}^{*}, \mathrm{~b}^{* * *}(77.6)$ & $0.704 \pm 0.008 \mathrm{a}^{* * *}, \mathrm{~b}^{\mathrm{NS}}(-23.14)$ & $1.14 \pm 0.42 \mathrm{a}^{* * *}, \mathrm{~b}^{* * *}(-60.82)$ \\
\hline 6. & T5 & $13.16 \pm 1.25 \mathrm{a}^{*}, \mathrm{~b} *(97)$ & $0.37 \pm 0.06 \mathrm{a}^{* * *}, \mathrm{~b}^{* * *}(-59.60)$ & $1.09 \pm 0.14 \mathrm{a}^{* * *}, \mathrm{~b}^{* * *}(-62.54)$ \\
\hline 7. & T6 & $13 \pm 0.5 \mathrm{a}^{* * *}, \mathrm{~b}^{* * *}(95.1)$ & $0.25 \pm 0.006 \mathrm{a}^{* * *}, \mathrm{~b}^{* * *}(-72.7)$ & $0.86 \pm 0.52 \mathrm{a}^{* * *}, \mathrm{~b}^{* * *}(-70.44)$ \\
\hline 8. & T7 & $12.5 \pm 0.86 a^{*}, b^{*}(87.6)$ & $0.45 \pm 0.02 \mathrm{a}^{* * *}, \mathrm{~b}^{* * *}(-50.8)$ & $0.82 \pm 0.30 \mathrm{a}^{* * *}, \mathrm{~b}^{* * *}(-71.82)$ \\
\hline
\end{tabular}

a indicates $\mathrm{p}$ value compared to control and b indicates $\mathrm{p}$ value compared to T1. ${ }^{*} \mathrm{p}$ value $<0.05$, ${ }^{* *} \mathrm{p}$ value $<0.01, * * * \mathrm{p}$ value $<0.001$

Parenthesis indicates percent increase or decrease compared to control.

Table 4. ANOVA- single factor between various treatments for different parameters

\begin{tabular}{|c|c|c|}
\hline Parameters & $F$ value between $T 2, T 3$ and $T 4$ & F value between $\mathrm{T} 5, \mathrm{~T} 6$ and $\mathrm{T} 7$ \\
\hline Fresh weight & 3.99 & $30.08^{*}$ \\
\hline Dry weight & 1.16 & $36.38^{*}$ \\
\hline Total sugar & $26.38^{*}$ & $10.68^{*}$ \\
\hline Protein & 3.81 & 0.33 \\
\hline Starch content & $10.33^{*}$ & 0.419 \\
\hline Amylase activity & $13.73^{*}$ & $18.20^{*}$ \\
\hline Cellulase activity & 1.75 & 0.51 \\
\hline
\end{tabular}

Tabulated F value at 2, 6 degree of freedom is 5.14. * indicates the difference is significant i.e. calculated $\mathrm{F}$ value $>$ tabulated $\mathrm{F}$ value

Table 5. Showing the correlation between various estimated parameters of banana harvested after different treatment from planting till harvesting

\begin{tabular}{|l|r|r|r|r|r|r|}
\hline & $\begin{array}{c}\text { Fresh } \\
\text { weight }\end{array}$ & $\begin{array}{c}\text { Dry } \\
\text { weight }\end{array}$ & $\begin{array}{c}\text { Total } \\
\text { sugar }\end{array}$ & Protein & $\begin{array}{c}\text { Cellulase } \\
\text { activity }\end{array}$ & $\begin{array}{c}\text { Amylase } \\
\text { activity }\end{array}$ \\
\hline Fresh weight & 1. & & & & & \\
\hline Dry weight & $0.78^{*}$ & 1 & & & & \\
\hline Total sugar & $0.24^{\mathrm{NS}}$ & $0.29^{\mathrm{NS}}$ & & & \\
\hline Protein & $-0.18^{\mathrm{NS}}$ & $0.22^{\mathrm{NS}}$ & $0.35^{\mathrm{NS}}$ & & & \\
\hline Starch & $0.57^{\mathrm{NS}}$ & $0.55^{\mathrm{NS}}$ & $0.57^{\mathrm{NS}}$ & $0.37^{\mathrm{NS}}$ & & \\
\hline Amylase activity & $-0.17^{\mathrm{NS}}$ & $-0.38^{\mathrm{NS}}$ & $-0.37^{\mathrm{NS}}$ & $-0.77^{*}$ & $-0.78^{*}$ & \\
\hline Cellulase activity & $-0.21^{\mathrm{NS}}$ & $-0.41^{\mathrm{NS}}$ & $-0.36^{\mathrm{NS}}$ & $-0.39^{\mathrm{NS}}$ & $-0.82^{*}$ & \\
\hline
\end{tabular}

Ns indicates insignificant correlation ( $\mathrm{p}$ value $>0.05),{ }^{*}$ indicates significant correlation ( $\mathrm{p}$ value $\left.<0.05\right)$ 


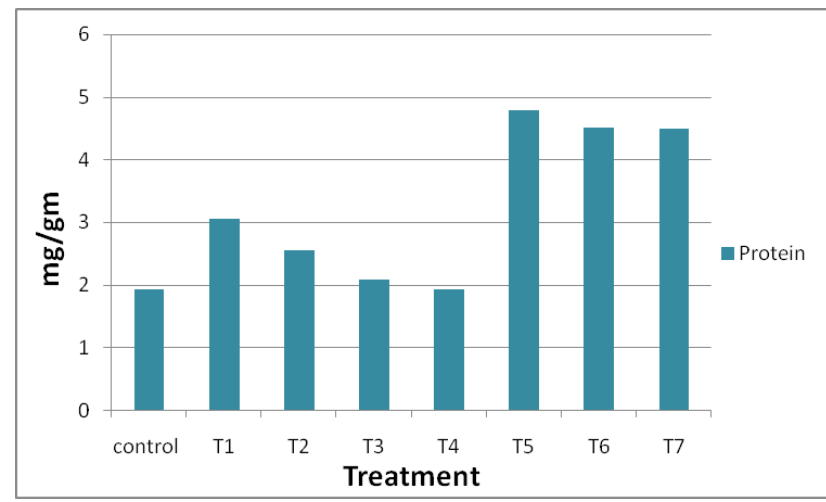

Fig. 2. Protein content in the pulp of banana harvested after different treatment from planting till harvesting.

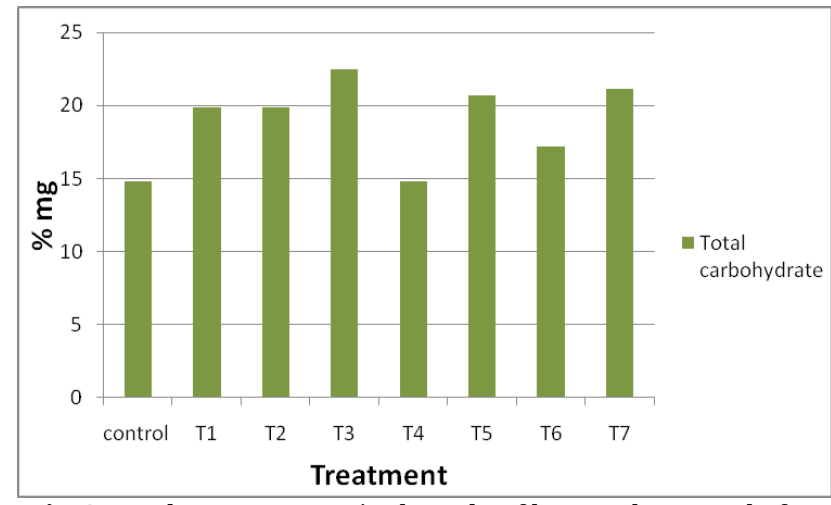

Fig. 3. Total sugar content in the pulp of banana harvested after different treatment from planting till harvesting.

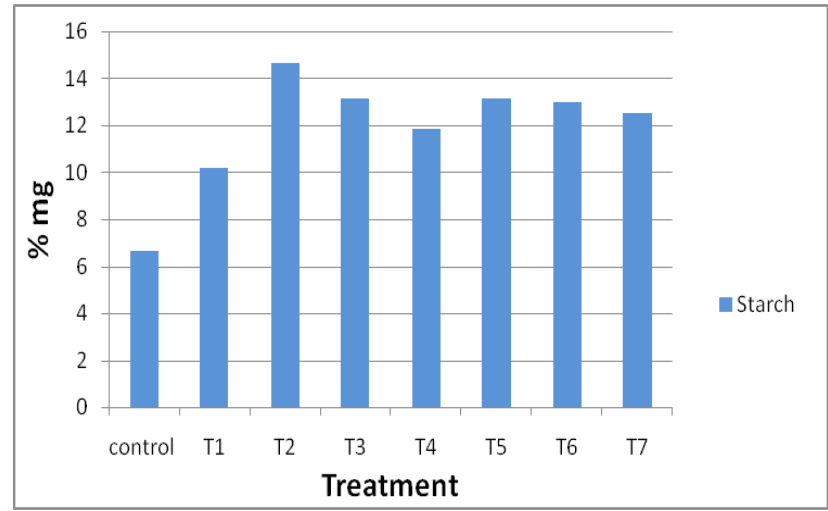

Fig. 4. Starch content in the pulp of banana harvested after different treatment from planting till harvesting.

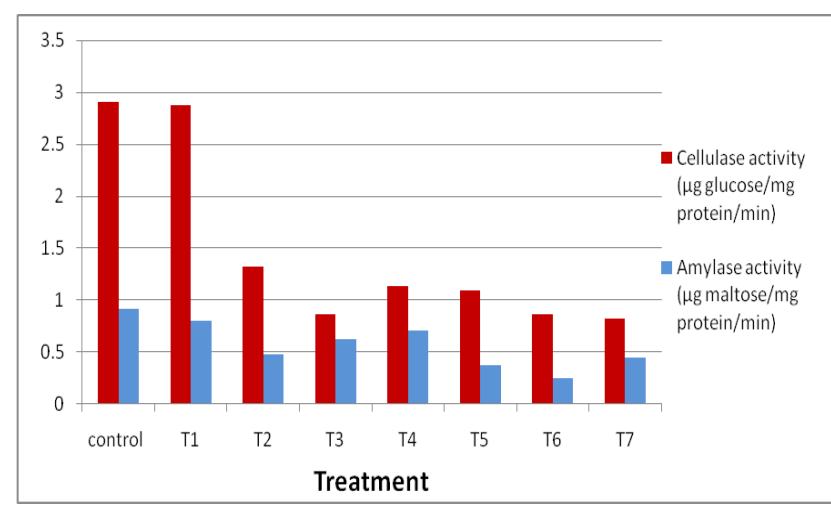

Fig. 5. Cellulase and amylase activity in the pulp of banana harvested after different treatment from planting till harvesting.

\section{Authors' contributions}

$\mathrm{AB}$ and $\mathrm{NV}$ devised and designed the experiment. RG provided the field for the experiment and helped in the design along with coordination for the experimental procedure. TR carried out experiments, data analysis and framed the research article under the guidance of $\mathrm{AB}$.

\section{Conflict of interests}

The authors do not have any conflict of interests to declare.

\section{References}

1. Guntzer F. Benefits of plant silicon for crops: a review. Agron. Sustain. Dev. 2012; 32: 201-13. https://doi.org/10.1007/s13593 011-0039-8

2. Gunes A, Inal A, Bagci EG, Coban S. Silicon mediated changes on some physiological and enzymatic parameters symptomatic of oxidative stress in barley grown in sodic-B toxic soil. J Plant Physiol.

https://doi.org/10.1016/j.jplph.2006.07.011

2007;164:807-11.

3. Ranganathan S, Suvarchala V, Rajesh YBRD, Prasad MS, Padmakumari AP, Voleti SR. Effects of silicon sources on its deposition, chlorophyll content and disease and pest resistance in rice. Biol Plant. 2006;50:713-16. https://doi.org/10.1007/s10535-006-0113-2

4. Balakhnina TI, Matichenkov VV, Wlodarczyk T, Borkowska A, Nosalewicz M, Fomina IR. Effects of silicon on growth processes and adaptive potential of barley plants under optimal soil watering and flooding. Plant Growth Regul. 2012; 67:35- 43. https://doi.org/10.1007/s10725-012-9658-6

5. Melo SP, Korndorfer GH, Korndorfer CM, Lana RM, Santan DG Silicon accumulation and water deficient tolerance in grasses. Scientia Agricola, 2003;60:755-59. https://doi.org/10.1590/S0103 90162003000400022

6. Pei ZF, Ming DF, Liu D, Wan GL, Geng XX, Gong HJ, Zhou WJ. Silicon Improves the tolerance of water--deficit stress induced by polyethylene glycol in wheat (Triticum aestivum L.) seedlings. Journal of Plant Growth Regulation. 2010;29:106-15. https://doi.org/10.1007/s00344-009-9120-9

7. Ali A, Basra S, Hussain S, Iqbal J. Increased growth and changes in wheat mineral composition through calcium silicate fertilisation under normal and saline field conditions. Chilean Journal of Agricultural Research. 2011;72(1):98-103. https://doi.org/10.4067/S0718-58392012000100016

8. Mali M, Aery NC. Influence of silicon on growth, relative water contents and uptake of silicon, calcium and potassium in wheat grown in nutrient solution. J Plant Nutr 2008;31:186776. https://doi.org/10.1080/01904160802402666

9. Ma JF, Miyake Y, Takahashi E. Chapter 2 Silicon as a beneficial element for crop plants. Studies in Plant Science. 2001;8(C):1739. https://doi.org/10.1016/S0928-3420(01)80006-9

10. Rains DW, Epstein E, Zasoski RJ, Aslam M,. Active silicon uptake by wheat. Plant Soil. 2006;280:223-28. https://doi.org/10.1007/s11104-005-3082-x

11. Biel KY, Matichenkov VV, Fomina IR. Protective role of silicon in living systems. In: Martirosyan DM (ed) Functional foods for chronic diseases. D\&A Inc., Richardson. 2008;208-31.

12. Jones DR. Introduction to banana, abacá and enset. In: Jones DR (ed). Diseases of Banana, Abacá and Enset. New York, CABI Publishing 1999.

13. Arias P, Dankers C, Liu P, Pilkauskas P. L'economie mondiale de la banane Rome: FAO Press. 2003; 1985-2002 (p. 102).

14. Murasoli M, Jambulingam S. A study on marketing of banana in manapparai and musuri taluks in Tiruchirappalli district of Tamilnadu. Int J Recent Sci Res. 2016;7(10):14040-44.

15. Henriet C, Draye X, Oppitz I, Swennen R, Delvaux B. Effects, distribution and uptake of silicon in banana (Musa spp.) under controlled conditions. Plant Soil. 2006;287:359-74 https://doi.org/10.1007/s11104-006-9085-4

16. Hedge JE, Hofreiter BT. In: Methods in Carbohydrate Chemistry. Vol.17, (eds.) Whistler RL, BeMiller JN, Academic Press, New York, 1962; 420.

17. Sadasivam S, Manickam A. In: Biochemical methods for Agricultural sciences. Wiley Eastern Limited, New Delhi, 1992;6-7;11-12.

18. Lowry OH, Rosebrough NJ, Farr AL, Randall RJ. Protein measurement with Folin phenol reagent. Journal of Biologica 
Chemistry. 1951;193:265-75. https://doi.org/10.1016/S00219258(19)52451-6

19. Sadasivam S, Manickam A. Biochemical Method. New Age. International (P) Limited, New Delhi, $2^{\text {nd }}$ ed. 1996.

20. Mitani N, Ma JF. Uptake system of silicon in different plant species. Journal of Experimental Botany. 2005;56(414):1255-61. https://doi.org/10.1093/jxb/eri121

21. Bharwana SA, Ali S, Farooq MA, Iqbal N, Abbas F, et al Alleviation of lead toxicity by silicon is related to elevated photosynthesis, antioxidant enzymes suppressed lead uptake and oxidative stress in cotton. J Bioremed Biodeg. 2013; 4(187):1-11. https://doi.org/10.4172/2155-6199.1000187

22. Gengmao Z, Shihui L, Xing S, Yizhou W, Zipan C. The role of silicon in physiology of the medicinal plant (Lonicera japonica L.) under salt stress. Sci Rep. 2015;5(12696):1-11. https://doi.org/10.1038/srep12696

23. Haghighi M, Pessarakli M. Influence of silicon and nanosilicon on salinity tolerance of cherry tomatoes (Solanum lycopersicum L.) at early growth stage. Scientia Horticulturae. 2013;161:111-17. https://doi.org/10.1016/j.scienta.2013.06.034

24. Zhu Z, Wei G, Li J, Qian Q, Yuet J. Silicon alleviates salt stress and increases antioxidant enzymes activity in leaves of saltstressed cucumber (Cucumis sativus L.). Plant Sci. 2004 167:527-33. $\quad$ https://doi.org/10.1016/j.scienta.2013.06.034 10.1016/j.plantsci.2004.04.020

25. Gong H, Zhu H. Chen K, Wang S, Zhang C. Silicon alleviates oxidative damage of wheat plants in pots under drought. Plant Sci. https://doi.org/10.1016/j.plantsci.2005.02.023 $2005: 169: 313-21$

26. Hanumanthaiah MR, Hipparagi K, Renuka DM, Vijendrakumar RC, Santhosha KV, Kumar KK. Effect of soil and foliar application of silicon on fruit quality parameters of banana cv. Neypoovan under hill zone. Plant Archives. 2015;15(1):221-24.

27. Soundararajan P, Sivanesan I, Jana S, Jeong BR. Influence of silicon supplementation on the growth and tolerance to high temperature in Salvia splendens. Hort Environ Biotechnol. 2014;55:271-79. https://doi.org/10.1007/s13580-014-0023-8

28. Abbas T, Balal RM, Shahid MA, Pervez MA, Ayyub CM, Aqueel $\mathrm{MA}$, et al. Silicon-induced alleviation of $\mathrm{NaCl}$ toxicity in okra (Abelmoschus esculentus) is associated with enhanced photosynthesis, osmoprotectants and antioxidant metabolism. Acta Physiol Plant. 2015;37(6):1-15 https://doi.org/10.1007/s11738-014-1768-5

29. Shwethakumari U. Effect of foliar application of silicic acid on growth, yield and quality of soybean [Glycine max (L.)]. In Proceedings of the $7^{\text {th }}$ International Conference on Silicon in Agriculture, Bengaluru, India. 2017;24-28:146.

30. Mohan T, Rajesh PN, Zuhra KF, Vijitha K. Magnitude of changes in the activity of amylases and cellulase and its association with the biochemical composition during maturation and ripening of banana (Musa spp.). Biochem Physiol. 2014;3(127):1-7. https://doi.org/10.4172/21689652.1000127

31. Stamatakis A, Papadantonakis N, Lydakis-Simantiris N, Kefalas P, Savvas D. Effects of silicon and salinity on fruit yield and quality of tomato grown hydroponically. Acta Hort 2003;609:141-47. https://doi.org/10.1016/j.scienta.2013.06.034 10.17660/ActaHortic.2003.609.18

32. Garcia E, Lajolo FM. Starch transformation during banana ripening: The amylase and glucosidase behavior. Journal of Food Science. 1988;53:1181-86. https://doi.org/10.1111/j.13652621.1988.tb13557.x

33. Bassinello PZ, Cordenunsi BR, Lajolo FM. Amylolytic activity in fruits: comparison of different substrates and methods using banana as model. J Agric Food Chem. 2002;50:5781-86. https://doi.org/10.1021/jf011370p

34. Pesis E, Fuchs Y, Zauberman G. Starch content and amylase activity in avocado fruit pulp. Journal of the American Society for Horticultural Science. 1978;103:673-76. 